\title{
Abundance and spatial distribution of Greater Rhea Rhea americana in two sites on the pampas grasslands with different land use
}

\author{
PAOLA F. GIORDANO, LAURA M. BELLIS, JOAQUÍN L. NAVARRO and \\ MÓNICA B. MARTELLA
}

\section{Summary}

In Argentina the original landscape structure of the pampas grasslands has changed rapidly due to intensified and specialized agricultural practices. The conversion of grasslands into croplands has been suggested as a threat to Greater Rhea Rhea americana populations. The main goals of this study were to estimate the abundance of Greater Rheas and to analyse the species' spatial distribution at two sites of the pampas region with different land use: agro-ecosystem and grassland. The former was mainly devoted to crop production whereas the latter was mostly used for livestock grazing. Data were collected through 14 aerial surveys from 1998 to 2001, and in 2004. Each survey consisted of six strip-transects per site, spaced at regular intervals. The total area surveyed represented $4 \%$ of each study site $\left(113 \mathrm{~km}^{2}\right.$ in the grassland and $95 \mathrm{~km}^{2}$ in the agro-ecosystem). Greater Rhea density $( \pm \mathrm{SE}$ ) was significantly higher in the grassland (from $0.22 \pm 0.11$ to $0.86 \pm 0.24$ ind. $\mathrm{km}^{-2}$ ) than in the agro-ecosystem (from $0.05 \pm 0.05$ to $0.12 \pm$ 0.08 ind. $\mathrm{km}^{-2}$ ). Greater Rheas occupied $51 \%$ of the study area in the grassland but less than $5 \%$ in the agro-ecosystem. They showed a wide and uniform spatial distribution in the former area, whereas in the latter individuals occurred in small and isolated clusters. These results raise concern about the future of the species because, over recent years, land has been increasingly used for crop production. Hence, if the current rate of change in land use continues, the conservation status of this species will be seriously affected.

\section{Resumen}

En Argentina, la estructura original de los pastizales pampeanos ha sufrido profundos cambios debido a la intensificación y especialización de las prácticas agrícolas. El reemplazo de pastizales por cultivos ha sido sugerido como una amenaza para las poblaciones silvestres de ñandú común Rhea americana. Los objetivos principales de este estudio fueron estimar la abundancia del ñandú común y analizar la distribución espacial de la especie en dos sitios de la región pampeana con diferente uso de la tierra: un agroecosistema y un pastizal. El primer sitio se caracteriza principalmente por la producción de cultivos mientras que la actividad predominante del segundo es la cría de ganado. Los datos fueron recolectados mediante 14 recuentos aéreos entre 1998 y 2001, y en 2004. Cada muestreo consistió en seis transectas de faja por sitio, colocadas a espacios regulares. El área muestreada representó el $4 \%$ del área total en cada sitio de estudio $\left(113 \mathrm{~km}^{2}\right.$ en el pastizal y $95 \mathrm{~km}^{2}$ en el agroecosistema). La densidad de los ñandúes ( $\pm \mathrm{ES}$ ) fue significativamente mayor en el pastizal (entre $0.22 \pm 0.11$ y $0.86 \pm 0.24$ ind. $\mathrm{km}^{-2}$ ) que en el agroecosistema (entre $0.05 \pm 0.05$ y $0.12 \pm 0.08$ ind. $\mathrm{km}^{-2}$ ). Los ñandúes ocuparon el $51 \%$ del área de estudio en el pastizal aunque menos del $5 \%$ en el agroecosistema. Los individuos presentaron una distribución espacial amplia y uniforme en el pastizal mientras que en el 
agroecosistema los ñandúes se encontraron en grupos pequeños y aislados entre sí. Estos resultados resultan preocupantes para el fururo de la especie porque durante los últimos años, la tierra ha sido utilizada de manera creciente para la producción de cultivos. En consecuencia, si la tasa actual de cambio en el uso de la tierra continúa, el estado de conservación de esta ratite se verá seriamente afectado.

\section{Introduction}

Grasslands are among the most human-modified and degraded habitats in the world (Guerschman and Paruelo 2004). Several bird populations are declining in North America (Vickery and Herkert 2001, Giuliano and Daves 2002) as well as in South America (Cardoso da Silva 1999, Cavalcanti 1999, Tubaro and Gabelli 1999), probably as a consequence of habitat conversion. However, knowledge about bird species status and distribution in South Amercia is still poor (Di Giacomo and Krapovickas 2005).

In Argentina, the original landscape structure of the pampas grasslands has been changing rapidly due to intensified and specialized agricultural practices (Díaz-Zorita et al. 2002, Brown et al. 2005a). This fact has been repeatedly mentioned as a threat to populations of Greater Rhea Rhea americana, which is an endemic bird species to South America and a typical inhabitant of the Argentine pampas grassland (Bucher and Nores 1988, Folch 1992, Codenotti and Alvarez 2000, Bazzano et al. 2002, Bellis et al. 2004, Herrera et al. 2004, Di Giacomo and Krapovickas 2005). Greater Rheas mostly persist in agro-ecosystems that include grasslands and pastures of both wild (e.g. Plantago lanceolata, Conyza bonariensis, Cirsium vulgare, Phyla canescens) and cultivated(e.g. alfalfa Medicago sativa) dicotyledonous species (Bellis et al. 2004), since both are preferred items in Greater Rhea's diet (Martella et al. 1996). However, nowadays several areas of the pampas grasslands as well as other similar habitats throughout the range of Greater Rhea in South America are exclusively devoted to grain production (Brown et al. 2005a).

As a consequence, there is an urgent need to gather information on how Greater Rheas could be affected by alternative land uses. Our goals in this work were to estimate the density of Greater Rhea populations and analyse the distribution of individuals at a large spatial scale, at two sites of central Argentina that exhibit different land use: agro-ecosystem and grassland.

\section{Methods}

\section{Study areas}

Data on population size and spatial distribution were collected at two sites of the Argentine pampas region, each located in the subregion known as Inland pampa. The study sites were selected on the basis of their conservation status: a semi-natural grassland area (central-southern San Luis province; $34^{\circ} \mathrm{OO}^{\prime} \mathrm{S}, 66^{\circ} \mathrm{II} \mathrm{I}^{\prime} \mathrm{W}$ ) and an agro-ecosystem (south-western Córdoba province; $33^{\circ} 30^{\prime} \mathrm{S}, 65^{\circ} \mathrm{W}$ ) (León et al. 1984, Brown et al. 2005a) (Figure 1).

Although most of the pampas (94\%) has been transformed into agro-ecosystems (Díaz-Zorita et al. 2002, Brown et al. 2005a), grasslands still persist in areas considered not suitable for agriculture. Previous studies (León and Anderson 1983, León et al. 1984) reported that changes in pristine vegetation have been less important in the semi-arid western extreme of the pampas than in other parts of that region. Hence, two study sites were selected: one located in the grassland, still resembling natural habitat of rheas, and the other in an agro-ecosystem close to the grassland site. The selected grassland is characterized by sandy soils and rolling hills with fixed and moving dunes (Anderson et al. 1970). Maximum summer temperatures can peak at $43^{\circ} \mathrm{C}$, while winter temperatures can be as low as $-15^{\circ} \mathrm{C}$. Annual average rainfall is approximately $450 \mathrm{~mm}$, concentrated between October and April. The main vegetation is composed of native grasses (Sorghastrum pellitum, Elyomurus muticus, Bothriochloa springfieldii, Chloris retusa, Schizachyrium plumigerum, Eragrostis lugens, Sporobolus subinclusus, 


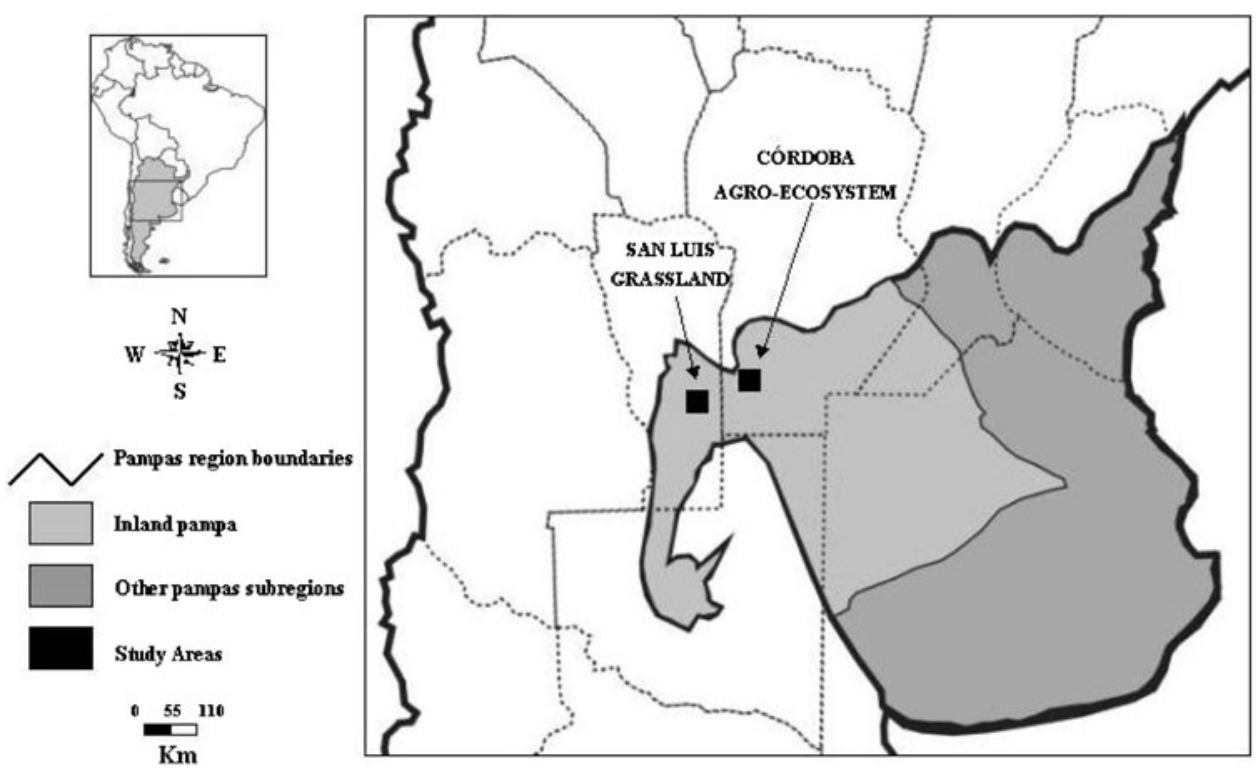

Figure 1. Location of the two study areas in the Inland pampa within the Argentine pampas region.

Aristida spegazzini, Poa ligularis and Poa lanuginosa), with small tree patches of Geoffrea decorticans, Prosopis caldenia and Prosopis alpataco (Anderson et al. 1970, Anderson 1973). Exotic grass species, such as Eragrostis curvula and Digitaria eriantha, were introduced to increase carrying capacity for livestock on ranches (Covas and Cairnie 1985). Land is mostly used for cattle-grazing and is only sporadically devoted to crop production because of the low annual rainfall (León et al. 1984), which in turn has contributed to maintaining its natural physiognomy. The study site in the grassland covered an area of $2,857 \mathrm{~km}^{2}$ and included almost all the area where habitat conversion has been less extensive.

The other selected study site, the agro-ecosystem, was $2,153 \mathrm{~km}^{2}$ in size; previous ground studies showed that Greater Rheas were present in this area (Sahade and Martella 1995, Martella et al. 1996). Unlike the neighbouring grassland study area, this agro-ecosystem has been severely transformed by agriculture and cattle-raising over the past 150 years (Díaz-Zorita et al. 2002, Brown et al. 2005a). Climate in the agro-ecosystem is temperate, with mean temperatures of $33^{\circ} \mathrm{C}$ in summer and $1.6^{\circ} \mathrm{C}$ in winter. The area is characterized by flat to gently rolling dunes. Rainfall is concentrated in the spring-autumn period (October-April) and the average annual rainfall is approximately $900 \mathrm{~mm}$ (Díaz-Zorita et al. 2002). The vegetation was originally composed of grasslands and forests, but is currently dominated by crops (Zea mays, Triticum aestivum, Glycine max, Arachis hypogaea; Díaz-Zorita et al. 2002) and pastures (Medicago sativa, Eragrostis sp., Agropyron sp., Bromus sp.; Ghersa and León 1999).

\section{Aerial survey}

We selected the aerial survey method for counting rheas because it is recommended for studies at large geographical scales, for open habitats, and for large and conspicuous individuals (Caughley 1974, Brown et al. 2005b, Sutherland 2005). A total of 14 aerial surveys, eight in the grassland and six in the agro-ecosystem, were conducted from 1998 to 2001 and in 2004. They 
were carried out in May (non-reproductive season) and December (post-reproductive season), because in both seasons rheas show aggregating behaviour and are more easily detected from the aircraft. Aerial counts were performed from a Cessna 182, flying at an average speed of $120 \mathrm{~km}$ $\mathrm{h}^{-1}$ and an average altitude of $100 \mathrm{~m}$. The flight direction was west to east and vice versa across each site, to avoid glare. Each survey consisted of six parallel strip-transects per site: the first transect was set on the northernmost part of the predetermined study areas and the other five were systematically set at regular intervals of $10.4 \mathrm{~km}$ in the grassland and $9.3 \mathrm{~km}$ in the agroecosystem (Figure 2). Two observers, seated side by side in a high-winged aircraft, recorded the number of Greater Rheas and the coordinates of sightings with a GPS. Each observer scanned a $170 \mathrm{~m}$-wide strip of ground on one side of the flight line (delineated by streamers on the aircraft's wing struts), leading to a total strip width of $340 \mathrm{~m}$. Each transect had an average length of $55 \mathrm{~km}$ in the grassland and $46 \mathrm{~km}$ in the agro-ecosystem, covering areas of approximately $19 \mathrm{~km}^{2}$ and $16 \mathrm{~km}^{2}$, respectively. Therefore, the total area surveyed was $113 \mathrm{~km}^{2}$ in the grassland and $95 \mathrm{~km}^{2}$ in the agro-ecosystem, which represents $4 \%$ of the area of each study site.

\section{Data analysis}

We used the simple estimate method for equal-sized sampling units to estimate Greater Rhea densities and their respective $95 \%$ confidence limits (Sinclair et al. 2006) and we used the Mann-Whitney $U$-test (Zar 1984) to detect differences in Greater Rhea densities between study sites.

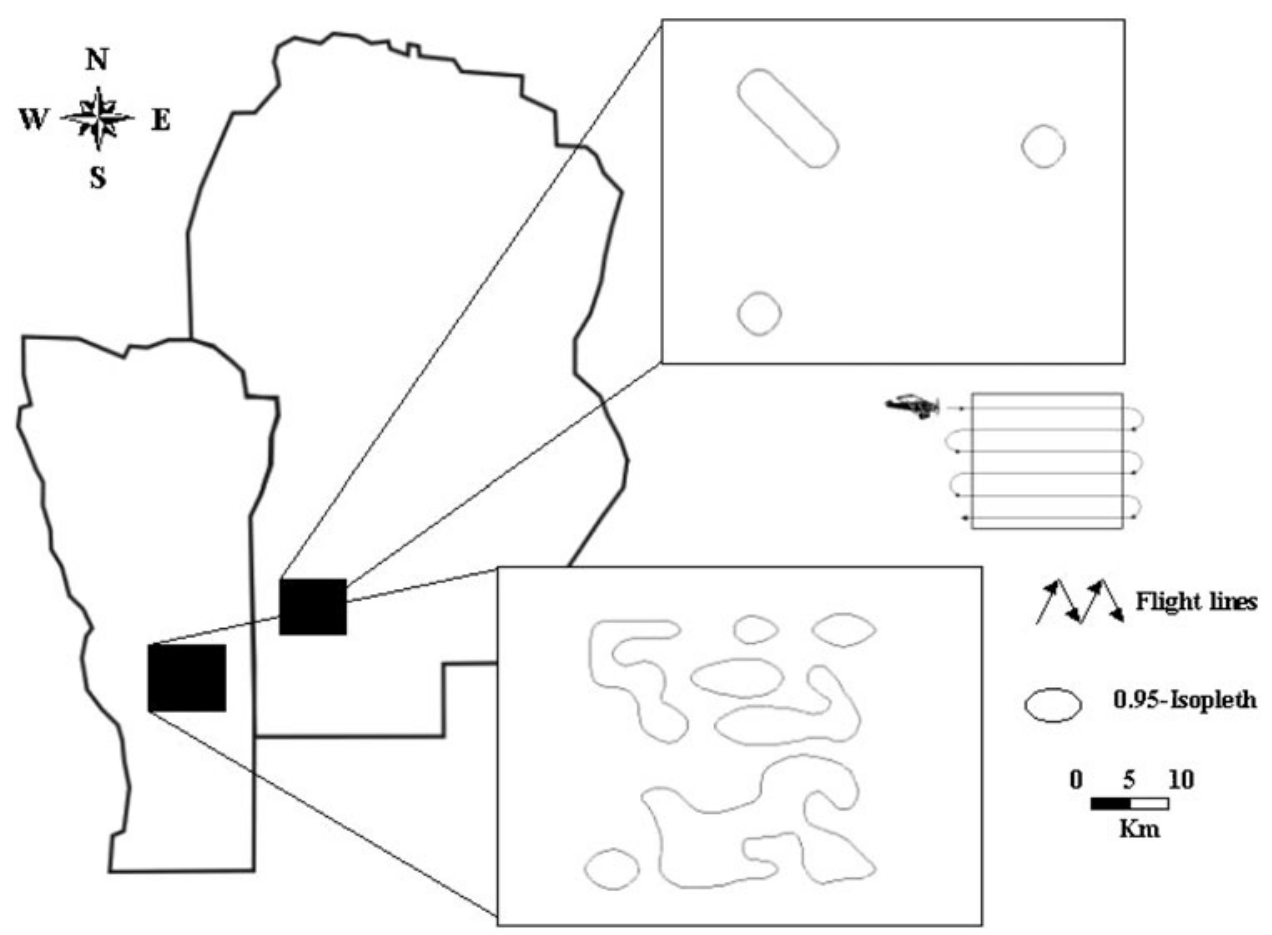

Figure 2. Spatial distribution of Greater Rheas, represented by 0.95 -isopleths estimated from aerial surveys in a grassland and in an agro-ecoystem of central Argentina, during 1998 to 2004 . 
To analyse the spatial distribution of Greater Rheas we created isopleths of population density, which are probability levels representing the proportion of observations that occur within them (Dixon and Chapman 1980, White and Garrot 1990, Reinert 1992). We estimated 0.95-isopleths (they include $95 \%$ of detections) based on data from all surveys pooled, using the non-parametric approach provided by the CAMRIS Geographic Information System (Ford 1998). With this method, the area over which rheas were surveyed was dissected by a grid and only those cells where one or more individuals were detected were considered.

\section{Results}

\section{Abundance and density}

Throughout the study, we recorded a total of 420 Greater Rheas, of which 404 (96\%) were sighted in the grassland and $16(4 \%)$ in the agro-ecosystem. Density of Greater Rheas $( \pm \mathrm{SE})$ was significantly higher in the grassland (from $0.22 \pm 0.11$ ind. $\mathrm{km}^{-2}$ to $0.86 \pm 0.24$ ind. $\mathrm{km}^{-2}$ ) than in the agro-ecosystem (from $0.05 \pm 0.05$ ind. $\mathrm{km}^{-2}$ to $0.12 \pm 0.08$ ind. $\mathrm{km}^{-2}$ ) (Table $\mathrm{I}$ ) (Mann-Whitney $U$-test $=1041.5 ; P<0.0001$ ).

In the grassland, the group size of rheas ranged from one to 20 individuals during the nonbreeding season, and from one to 11 in the post-reproductive season. Most groups observed at this site in both seasons consisted of two individuals. In the agro-ecosystem, group size was between one and seven individuals in the non-reproductive season, while not a single rhea was detected from the aircraft in the post-reproductive season. The groups most frequently observed consisted of four rheas.

\section{Spatial distribution}

The resulting isopleths visually identify those areas used by Greater Rheas at each site (Figure 2). In the grassland seven isopleths were defined, comprising a total area of $1,459 \mathrm{~km}^{2}$. At this site, the spatial distribution of individuals showed a wide and uniform pattern. In the agroecosystem, only three isopleths were identified. Greater Rheas occurred in small clusters that

Table 1. Greater Rhea densities, their respective confidence limits (CL) and group sizes obtained from aerial surveys conducted from 1998 to 2004 in a grassland and an agro-ecosystem of central Argentina.

\begin{tabular}{|c|c|c|c|c|c|}
\hline \multirow[t]{2}{*}{ Area } & \multirow[t]{2}{*}{ Year } & \multicolumn{2}{|c|}{ Density (individuals $/ \mathrm{km}^{2}$ ) } & \multirow{2}{*}{$\begin{array}{l}\text { Modal group } \\
\text { size }\end{array}$} & \multirow{2}{*}{$\begin{array}{l}\text { Group size } \\
\text { range }\end{array}$} \\
\hline & & Estimate & $\pm 95 \% \mathrm{CL}$ & & \\
\hline \multirow[t]{8}{*}{ Grassland } & $1998^{a}$ & 0.86 & 0.62 & 1 & $1-20$ \\
\hline & $1998^{b}$ & 0.46 & 0.44 & 2 & $0-11$ \\
\hline & $1999^{a}$ & 0.45 & 0.49 & 2 & $1-14$ \\
\hline & $2000^{a}$ & 0.22 & 0.28 & 2 & $1-11$ \\
\hline & $2000^{b}$ & 0.23 & 0.25 & $1-2$ & $0-5$ \\
\hline & $2001^{a}$ & 0.29 & 0.44 & $1-2$ & $0-13$ \\
\hline & $2001^{a}$ & 0.55 & 0.41 & 1 & $1-12$ \\
\hline & $2004^{a}$ & 0.52 & 0.59 & 2 & $1-20$ \\
\hline \multirow[t]{6}{*}{ Agro-ecosystem } & $1998^{a}$ & Not detected & - & - & - \\
\hline & $1999^{a}$ & 0.12 & 0.2 & 4 & $0-7$ \\
\hline & $2000^{a}$ & 0.05 & 0.13 & 4 & $\mathrm{O}-4$ \\
\hline & $2000^{b}$ & Not detected & - & - & - \\
\hline & $2001^{a}$ & Not detected & - & - & - \\
\hline & $2004^{a}$ & Not detected & - & - & - \\
\hline
\end{tabular}

${ }^{a}$ Non-breeding season and ${ }^{b}$ post-reproductive season. We use the term 'Not detected' because not a single rhea was observed. 
comprised $110 \mathrm{~km}^{2}$ in total and exhibited an uneven and restricted spatial distribution. These results show that Greater Rheas occupied $51 \%$ of the grassland but less than $5 \%$ of the agroecosystem.

\section{Discussion}

Our study stresses the differences in current status of Greater Rhea populations in two large areas of the Argentine pampas grasslands with alternative land uses. The dramatic contrast in abundance and spatial distribution pattern of the species between the grassland and the agroecosystem seems to be related to the type of land use practised in each area and, consequently, to spatial distribution and availability of resources.

In the grassland area, the low proportion of croplands (13\%; P. F. G. unpubl. data) compared with that of grasslands and pasturelands is perhaps the main reason for the higher density and larger spatial distribution of Greater Rheas. In contrast, in the agro-ecosystem, most lands are currently devoted to grain production, subjecting Greater Rhea populations to disturbances driven by agricultural practices.

Only a few isolated wild populations of Greater Rheas persist in the agro-ecosystem. Those small clusters of individuals may be inhabiting ranches that have a mixture of grasses, pastures and crops. This hypothesis is supported by subsequent field ground studies (P. F. G. unpubl. data) conducted within some ranches that spatially coincide with the area defined by isopleths and where the above-mentioned habitat types were present. Therefore, this fact suggests that Greater Rheas are restricted to those private ranches where land-owners are in favour of conservation and that have become small protected areas currently ensuring the survival and reproduction of this bird species.

Since Greater Rheas' abundance and spatial distribution have not been estimated in central Argentina, this work provides novel and relevant information that can serve as the baseline for future monitoring studies. Our research also shows that habitat transformation, specifically the conversion of grasslands into croplands, has a strong and negative impact on Greater Rhea populations. As increasing grain production appears to be inevitable, and given that most of the grassland remnants in central Argentina are on privately owned land, the long-term persistence of Greater Rheas will partly depend on the development of education and outreach plans for stakeholders and adequate government policies encouraging conservation of grasslands and implantation of pastures throughout the geographical range of the species.

\section{Acknowledgements}

We are grateful to P. Vignolo, C. Dellafiore, the staff of Aeroclub Río Cuarto (Córdoba province), and to the Quinta Brigada Aérea at Villa Reynolds (Argentine Air Force) for their assistance during the surveys. We thank Drs Martin Fisher, Gary White and two anonymous reviewers for helpful advice, comments and suggestions on earlier drafts of the manuscript. L.M.B. and P.F.G. were supported by fellowships from the Consejo Nacional de Investigaciones Científicas y Técnicas (CONICET). Funding for this work was provided to M.B.M. by the Fondo para la Investigación Científica y Tecnológica, the Secretaría de Ciencia y Técnica of the Universidad Nacional de Córdoba, and CONICET (L.M.B., J.L.N. and M.B.M. are researchers of CONICET).

\section{References}

Anderson, D. L. (1973) La distribución de Sorghastrum pellitum (Poaceae) en la

provincia de San Luis y su significado ecológico. Kurtziana 12: 37-45. 
Anderson, D. L., Del Águila, J. A. and Bernardon, A. E. (1970) Las formaciones vegetales de la provincia de San Luis. Rev. Inv. Agropecuaria INTA, serie 2, Biología y Producción Vegetal 7: 83-153.

Bazzano, G., Martella, M. B., Navarro, J., Bruera, N. and Corbella, C. (2002) Uso de hábitat por el ñandú (Rhea americana) en un refugio de vida silvestre: implicancias para la conservación y manejo de la especie. Ornitologia Neotropical 13: 9-15.

Bellis, L. M., Martella, M. B. and Navarro, J. L. (2004) Habitat use by wild and captivereared greater rheas in agricultural landscapes. Oryx 38: 304-310.

Brown, A., Martínez Ortiz, U., Acerbi, M. and Corcuera, J. (2005a) Situación ambiental argentina 2005. Third edition. Buenos Aires: Fundación Vida Silvestre Argentina.

Brown, S., Schulte, S., Harrington, B., Winn, B., Bart, J. and Howe, M. (2005b) Population size and winter distribution of eastern american oystercatchers. J. Wildl. Manage. 69: 1538-1545.

Bucher, E. H. and Nores, M. (1988) Present status of birds in steppes and savannas of northern and central Argentina. Pp. 71-79 in P. D. Goriup, ed. Ecology and conservation of grassland birds. Cambridge, U.K.: ICBP Tech. Publ. No. 7.

Cardoso da Silva, J. M. (1999) Seasonal movements and conservation of seedeaters of the genus Sporophila in South America. Stud. Avian Biol. 19: 272-280.

Caughley, G. (1974) Bias in aerial survey. J. Wildl. Manage. 38: 921-933.

Cavalcanti, R. B. (1999) Bird species richness and conservation in the cerrado region of Central Brazil. Stud. Avian Biol. 19: 244-249.

Codenotti, T. L. and Alvarez, F. (2000) Habitat use by Greater rheas Rhea americana in an agricultural area of southern Brazil. Rev. Etol. 2: 77-84.

Covas, G. and Cairnie, A. (1985) El pasto llorón. Manual con información básica y normas para su cultivo y utilización. Buenos Aires, Argentina: Ed. Hemisferio Sur.

Díaz-Zorita, M., Duarte, G. A. and Grove, J. H. (2002) A review of no-till systems and soil management for sustainable crop production in the sub-humid and semiarid
Pampas of Argentina. Soil Tillage Res. 65: $1-18$.

Di Giacomo, A. S. and Krapovickas, S. (2005) Conserving the grassland important bird areas (IBAs) of Southern South America: Argentina, Uruguay, Paraguay, and Brazil. Technical Report. Washington, D.C.: U.S. Department of Agriculture, Forest Service.

Dixon, K. R. and Chapman, J. A. (1980) Harmonic mean measure of animal activity areas. Ecology 61: 1040-1044.

Folch, A. (1992) Order Struthioniformes. Pp. 84-89 in J. Del Hoyo, A. Elliot and J. Sargatal, eds. Handbook of the birds of the world. Volume 1. Barcelona, Spain: Lynx Editions.

Ford, R. G. (1998) Advanced exercises. Pp. 70-92 in Computer aided mapping and resource inventory system - CAMRIS: Manual del usuario. Portland, U.S.A: Ecological Consulting Inc.

Ghersa, C. M. and León, R. J. C. (1999) Successional changes in agro-ecosystems of the rolling pampa. Pp. 487-502 in L. R. Walker, ed. Ecosystems of disturbed ground. Amsterdam: Elsevier. Ecosystems of the World 16.

Giuliano, W. M. and Daves, S. E. (2002) Avian response to warm-season grass use in pasture and hayfield management. Biol. Conserv. 106: 1-9.

Guerschman, J. P. and Paruelo, J. M. (2004) Agricultural impacts on ecosystem functioning in temperate areas of North and South America. Global and Planetary Change 47: 170-180.

Herrera, L. P., Comparatore, V. M. and Laterra, P. (2004) Habitat relations of Rhea americana in an agroecosystem of Buenos Aires Province, Argentina. Biol. Conserv. 119: 363-369.

León, R. J. C. and Anderson, D. L. (1983) El límite occidental del pastizal pampeano. Tuexenia 3: 67-83.

León, R. J. C., Rusch, G. M. and Oesterheld, M. (1984) Pastizales pampeanos: impacto agropecuario. Phytocoenologia 12: 201218.

Martella, M. B., Navarro, J. L., Gonnet, J. M. and Monge, S. A. (1996) Diet of greater rheas in an agroecosystem of central Argentina. J. Wildl. Manage. 60: 586-592. 
Reinert, H. K. (1992) Radiotelemetric field studies of pitvipers: data acquisition and analysis. Pp. 185-198 in J. A. Campbell and E. Brodie, eds. The biology of the pitvipers. Tyler, Texas: Selva.

Sahade, R. and Martella, M. B. (1995) Selección de habitat por el ñandú (Rhea americana) en un agroecosistema del sur de Córdoba, Argentina. Pp. 71 in XVII Reunión Argentina de Ecología. Mar del Plata, Argentina.

Sinclair, A. R. E., Fryxell, J. M. and Caughley, G., eds. (2006) Wildlife ecology, conservation, and management. Massachusetts, U.S.A: Blackwell Scientific.

Sutherland, W., ed. (2005) Bird ecology and conservation. A handbook of techniques.
Cambridge, U.K: Cambridge University Press.

Tubaro, P. L. and Gabelli, F. M. (1999) The decline of the Pampas Meadowlark (Sturnella defilippii): difficulties of applying the IUCN criteria to Neotropical grassland birds. Stud. Avian Biol. 19: 250-257.

Vickery, P. D. and Herkert, J. R. (2001) Recent advances in grassland bird research: where do we go from here? The Auk 118: 11-15.

White, G. C. and Garrot, R. A., eds. (1990) Analysis of wildlife radio-tracking data. California, U.S.A.: Academic Press.

Zar, J. H. (1984) Biostatistical analysis. New Jersey, U.S.A.: Prentice-Hall.

\section{PAOLA F. GIORDANO*}

Centro de Zoología Aplicada, Universidad Nacional de Córdoba, CC 122, CP: 500o, Córdoba, Argentina.

LAURA M. BELLIS

Cátedra de Ecología, Facultad de Ciencias Exactas Físicas y Naturales, Universidad Nacional de Córdoba, Vélez Sarsfield 299, CP: 500o, Córdoba, Argentina.

JOAQUÍN L. NAVARRO, MÓNICA B. MARTELLA

Centro de Zoología Aplicada, Universidad Nacional de Córdoba, CC 122, CP: 50oo, Córdoba, Argentina.

${ }^{*}$ Author for correspondence; e-mail:pgiordano@com.uncor.edu

Received 5 September 2006; revision accepted 26 April 2007 